\title{
Private Forests in Nepal: Status and Policy Analysis
}

\author{
Swoyambbu M. Amatya ${ }^{1}$ and Prakash Lamsal ${ }^{2}$ \\ ${ }^{1}$ Former Secretary, Government of Nepal, ${ }^{2}$ Department of Forests, Government of Nepal
}

Corresponding author: swoyambhu_amatya@yahoo.com

\begin{abstract}
This paper reviews and analyses the present status of private forests and tenure administration in light of existing legal, policy, and regulatory frameworks in Nepal. Additionally, the present status of private forests, as well as the scenarios of timber harvesting, transportation, marketing, and their administration are thoroughly revised. Provisions regarding forests and trees on private land and their basis are examined and implications are articulated for potential policy improvements for enhanced tenure security. It is shown that robust national-level policies and legal frameworks exist, and that there is an increasing trend of timber flows to markets from private forests over the past five years. However, there is still skepticism, mistrust and fear amongst private forest owners, saw millers, and forest administration that prevents the full use of the bundle of rights that legal and policy provisions have promised. An unusually slow pace of private forest registration, lengthy and multi stage processes for obtaining harvesting and transportation permits, and official bans on important commercial species, among others, are found to be the factors that most hinder the private forest owners' and tree growers' interests, and their rights and obligations with respect to the management and use of their private forest resources. It is concluded that a simplified permitting process along with programmatic support would promote and help to grow private forestry and that Nepal's experience and lessons learned from community forest implementation would be a great asset to move towards this end. Connecting community forest user groups for organised and cooperative action, and mobilising their institutional strength and accumulated funds for pro-farmer technical and regulatory support would allow farmers to intensify tree plantations and forest management. Further steps are required to convince policymakers and secure necessary budgetary support to this end.
\end{abstract}

Key words: Forest farmers, forest tenure, policy, private forest, timber flow

\section{INTRODUCTION}

The relationship between the institutions and individuals governing forests affect actions inside the forest and beyond. Tenure rights determine the nature of resource governance, and the scope and mechanism of its transformation. A review of global literature on forest tenure rights describes two primary types of tenure rights: the rights that are defined by statutory law (i.e., de jure) and by local practice (i.e., de facto). The Food and Agriculture Organization (FAO) defines tenure as the mechanisms and processes through which citizens and groups can articulate their interests (FAO 2014), mediate their differences, and exercise their rights and obligations with respect to the management and use of resources including forests. A thorough understanding and analysis of the tenure system and its administration has many implications in the formulation of strategies, policies, and operational procedures to administer private forests $(\mathrm{PFs})$ - trees on private land.

This paper analyses the Nepalese tenure system for PFs in light of present legal and regulatory frameworks and their operational procedures. The historical evolution of PFs and their current status are briefly presented on the outset, followed by a description of timber flows 
to the market from PFs. Policy and legal provisions related to PFs are discussed and their operational implementation, especially focusing on PF registration and issuances of harvesting and transportation permits are critically reviewed. The questions-why PF development in the country is slow and what factors drive the communities and individuals to plant and raise trees in their private land-are discussed and an attempt is made to answer these questions. Key issues and challenges for strengthening PF tenure are discussed and conclusions and recommendations are drawn for future policy improvement.

\section{HISTORICAL EVOLUTION AND CURRENT STATUS OF PRIVATE FORESTS IN NEPAL}

PFs have been integral part of the Nepalese farming systems and rural livelihoods from time immemorial. Almost 83 per cent of the total population reside in rural areas (CBS 2015) and primarily depend on subsistence farming systems for livelihoods. Considering the dependency of rural populations on forest products for basic livelihoods, it can be presumed that most of the population residing on such areas would practice tree-based farming systems to some degree. Recorded history goes back to King Jayasthiti Malla in 1379, when a legal provision to develop forests on any private land uncultivated for five years or more was established. This was adopted even after the unification of Nepal by King Prithivi Narayan Shah and continued by Rana Prime Ministers (Acharya and Baral 2016). Rana Prime Minister Juddha Sumsher started a rule to plant at least one sapling before cutting a mature tree from one's private land. This can be considered a historical milestone of PF development in Nepal.
The Private Forests Nationalisation Act was promulgated in the year 1957. One of the objectives of this Act was to nationalise privately owned forests of the county. The Act provisioned a limitation on PF ownership. It allowed a private individual to own a maximum of 25 ropani $(1.3 \mathrm{ha})$ of $\mathrm{PF}$ in the hills or 5 bighas $(3.4 \mathrm{ha})$ in the Terai. This limitation led to negative impacts on planting trees on private lands. Farmers virtually stopped planting trees on their land. One of the reasons that farmers stopped planting trees on private lands was the fear that the government would further limit the area of PFs. This scenario continued until late 1980s.

PFs have been at the heart of policy making since the inception of the Master Plan for the Forestry Sector (MPFS) in 1989. In line with the MPFS, the Forest Act was promulgated in the year 1993 and its regulations were prepared in the year 1995. The Forest Act 1993 and Regulations 1995 included specific provisions for PFs and thereby legalised and also institutionalised the development of PFs in the county. In order to provide the services spelled out in the Act and Regulations, the Department of Forest (DoF) was restructured with the establishment of the Community and Private Forestry Division in the year 1993.

$\mathrm{PF}$ is one of the forest management regimes in Nepal, where the tenure rights related to private lands cannot be terminated without due process and without payment of reasonable compensation by the government or other institutions. The tenure rights of $\mathrm{PF}$ are detailed in the Forest Act 1993 and the Forest Regulations 1995. According to the Forest Act 1993, PF is defined as 'a forest planted, nurtured or conserved in any private land owned by an individual pursuant to prevailing laws' 
(HMGN 1993: pp. 3). This indicates that the ownership rights pertain to both the land and the forest resources on it. There are two legal categories of PF currently in operation in the country, but in practice PF can be differentiated into three types. The first type is the once that is registered at the District Forest Offices (DFOs) in which tenure rights rest on the individual owners, who can plant, harvest, and sell trees and tree products as per prevailing rules and regulations. The second type is $\mathrm{PF}$ that is in practice but is not registered at the DFOs, but for which an individual farmer has his/her land ownership certificate issued by cadastral survey. The land owner can harvest, use, and sell trees and tree products grown naturally or artificially, but has to get prior approval from the DFO. The third type is de facto, with trees grown and managed on public land by farmers who claim tenure rights over these tree crops but have neither land nor tree ownership certificates. A rapid survey conducted in February 2017 at Methinkot in Kavre district indicated that of the six-interviewed farmers, none had registered his or her forest at DFOs and only one had a land ownership certificate. While this is not a representative example of all Kavre residents, it does indicate that many people do not have private lands and forests that are legally registered at the DFOs.

The extent and coverage of registered PFs in the country is not very encouraging. The DoF's latest report shows that of the total 75 districts, only 62 districts have records of PFs and their registration. Only 3,753 private individuals have registered 2,902 ha of their forests as PFs at their respective DFOs (CFD 2017). Data shows that the Southern plain (Terai) districts have higher number of PFs in comparison to hill districts. Table 1 depicts the number of registered PFs from ten districts, five each from the hill and Terai districts, selected on the basis of the higher number of PFs registered at DFOs (CFD 2017). Observations of farmers' field site in the Terai shows that trees on private farms are mostly planted, whereas trees in the hills are usually grown naturally and protected by farmers.

Table 1: Terai and Hill Districts with the Highest Number of Registered Private Forests

\begin{tabular}{llll}
\hline Terai districts & Number & Hill districts & Number \\
\hline Morang & 503 & Solukhumbu & 133 \\
Jhapa & 380 & Tanahun & 74 \\
Sunsari & 362 & Dhankuta & 56 \\
Chitwan & 212 & Khotang & 56 \\
Dhanusa & 201 & Surkhet & 51 \\
\hline
\end{tabular}

Source: CFD 2017

Table 1 shows that the hill districts have fewer registered PFs. In contrast to these figures of registered $\mathrm{PFs}$, it has been reported that a total of 54,890 ha private land contains compact plantations with 5.5 million trees in total, and there are other 2.6 million trees scattered on private lands (CBS 2013). One possible reason for not registering PFs could be that the process of registration does not entail any additional benefits to farmers. Farmers have, therefore, remained indifferent to registering their PFs. Furthermore, the framework structures of $\mathrm{PFs}$ are varied; 
The DoF has identified a total of 10 different PF types ${ }^{1}$ based on the pattern of plantation and timber utilisation $(\mathrm{DoF}$ 2015).

\section{WOOD FLOWS FROM PRIVATE FORESTS}

Timber and fuelwood flows from PFs are provided in Table 2 (CFD 2017). Despite a very small number of PFs registered in the country, a total $321,867 \mathrm{~m}^{3}$ of timber was sold in the market in the fiscal year 2015/2016. The share of timber supplied in the market from the PF is very high $(83.17 \%)$, higher than from community forests (CFs) or government-managed forests (CFD 2017). It is surprising to see such a high volume of wood coming from small area (2,902 ha) of land. Much of the timber and fuelwood could have come from other sources, including from unregistered PFs with scattered trees. A study carried out by Amatya et al. (2015) showed that mainly Pinus roxburghii and Alnus nepalensis, followed by Schima wallichi, are the main tree species grown on private land that contribute to sawmills in Sindhupalchok, Kavrepalanchok, and Lamjung districts.

Table 2: Timber and Fuelwood Sold in the Market

\begin{tabular}{|c|c|c|c|}
\hline \multirow[t]{2}{*}{ S.N. } & \multirow[t]{2}{*}{ Forest tenure types } & \multicolumn{2}{|c|}{ Product category } \\
\hline & & Fuelwood $\left(\mathrm{m}^{3}\right)$ & Timber $\left(\mathrm{m}^{3}\right)$ \\
\hline 1 & Private forest & 69,332 & 267,710 \\
\hline 2 & Community forest & 20,852 & 31,285 \\
\hline 3 & $\begin{array}{c}\text { Government-managed forest } \\
\text { Total }\end{array}$ & $\begin{array}{c}17,940 \\
108,124\end{array}$ & $\begin{array}{c}22,871 \\
321,866\end{array}$ \\
\hline
\end{tabular}

Source: CFD (2017)

PFs are not only fulfilling the market and industrial demands but also significantly contributing to the national economy by providing employment opportunities and tax revenues. Sawmills, plywood factories, and other forest based enterprises have been using timbers obtained primarily from PFs. Their contribution to the national economy in terms of only Value Added Tax (VAT) is also very large (Table 3). VAT, equivalent to 13 per cent of the government royalty rate, is levied on timber supplied from PFs to the market.

${ }^{1}$ PFs in i) Private forests in blocks, ii) Private forests as alley cropping, iii) Forests along river banks or streams, iv) Private forests in the form of home gardens, v) Trees along the bounds of fish ponds, vi)Trees in horticultural farms, vii) Private forests for recreation, viii) Agroforestry Private forests in the form of green hedges ix) Private forests as industrial forests
The increasing timber supply trend from PFs over the last five years can mainly be attributed to expanding road access to rural areas which has significantly reduced transportation costs, and has led to growing market demand.

Table 3. Revenue Collected as VAT from Privater Forest

\begin{tabular}{ccc}
\hline Fiscal & \multicolumn{2}{c}{ Revenue collected as VAT } \\
\cline { 2 - 3 } Year (BS) & Cubic meter & $\begin{array}{c}\text { Equivalent } \\
\text { US\$ }\end{array}$ \\
\hline $2068 / 69$ & 88,449 & 559,989 \\
$2069 / 70$ & 93,378 & $1,039,571$ \\
$2070 / 71$ & 227,824 & $1,249,330$ \\
$2071 / 72$ & 260,833 & $1,484,715$ \\
$2072 / 73$ & 267,710 & $1,618,211$ \\
\hline
\end{tabular}

Currency exchange rate 1 US $\$=$ NRs 99

Source: CFD (2017) 


\section{PRIVATE FORESTRY POLICY PROVISIONS}

The Constitution of Nepal (2015), through its directive principles, promotes and protects the rights of individuals and their property, and has recognised the role of the private sector. In line with this, the Forest Policy 2015 and Forestry Sector Strategy 2016 have acknowledged the role of PFs and emphasised on the partnership between private actors, public officials, and the community in developing forest entrepreneurship.

The Forest Act 1993 has classified and clearly defined forests into two main categories for the purpose of their management: national forests and PFs. The ownership and control of national forests belong to the government, whereas the ownership and control of PFs belongs to the individual landowner. The rights to use, exclude, and alienate the private land rests with the individual owning the land. However, the bundle of rights over trees and forests in these private lands is highly regulated by the government. The Forest Act 1993, Forest Regulations 1995 and Private Forest Development Directives 2011 ("the directives") published by the DoF in 2013 (with amendments) have provisioned the PF registration process, issuance of harvesting and transportation permits of forest products and procedures for other supports to the forest owners. Amidst the legal provision of getting government support for PFs (Preamble, Article 38, Article 39 of Forest Act 1993, Rules 61-64 of Forest Regulations 1995),
$\mathrm{PF}$ registration is not obligatory, but is discretionary for individuals growing trees on their private land. Individuals willing to register their $\mathrm{PF}$ are required to submit an application to the DFO along with the tax payment receipt, land ownership, and citizenship certificates. The Forest Regulations 1995 (Rules 6164) describe procedures for applying for $\mathrm{PF}$ registration, issuing certificates for $\mathrm{PFs}$, and the application and issuance of harvesting and transportation permits of forest products from PFs.

Recent (in 2015) amendments to Forest Regulations 1995 have provisioned more simple and farmer-friendly processes for the development of PFs. As per their wish, farmers can now directly harvest, sell, and transport 23 common trees species which are mostly grown on private lands (GoN 2015). Planted Sisam (Dalbergia sissoo), Teak (Tectona grandis), Tooni (Toona ciliata), Masala (Eucalyptus species), Kadam (Anthosephalous cadamba) and Aap (Mangifera indica) are popular among those 23 species. However, it is necessary for individual farmers to visit the concerned forest office only once to register and endorse the stock and obtain permits for transporting the harvested timber.

Similarly, in a bid to promote PF in the country, the Private Forest Development Directives were brought into operation in 2011. Chapter 3, clause 7 (d) of the directives provides a list of 26 tree species suitable for planting on private land (GoN 2011). The directives have recommended that these trees be planted mainly in two ecological zones (hill and Terai). 
REVIEW OF REGULATORY AND OPERATIONAL PROCEDURES FOR PRIVATE FORESTRY

There is a clear provision in the Forest Act of 1993 (Section 38) that says that PF owners, whether registered or unregistered, can manage their forests, harvest forest products, and use or sell them freely in the market. However, the Forest Regulations 1995 (Rule 62) has made different arrangements for registered and unregistered private forests. Unregistered PF owners have to follow a multi-stage process to harvest and sell forest products. Application to the DFO, field verification by DFO field staff, and the issuance of harvesting permits by the DFO as well as transportation permit by the DFO are the prerequisites, which demand certain time for the private owners to have their names registered. Registered PF owners can harvest, sell, and freely transport products to the market with prior information provided to the local DFO. This shows that $\mathrm{PF}$ owners first have to register with the DFO to enjoy the rights spelled out by the Forest Act 1993. Normally, people are allowed to work in the forest for eight months (Kartik to Jestha or midOctober to mid-June) per year, excluding the monsoon period. While this rule is exclusively intended for governmentmanaged forests, it is also applied to the community forests and PFs by forestry staff. PF owners do not get tree-harvesting permits for sale and transportation during the four months from June to September.

Amatya et al. (2015) have observed that there are more than fourteen steps (Figure 1) that private tree owners have to fulfill before harvesting and selling trees planted on their registered private land. These steps are very lengthy and difficult to abide in practice. Pandit et al. (2014) report that a private tree owner who wants to transport products from one place to another needs to pay the required royalty amount and get the transportation permit (Chod Purji) from the DFO. The permit comes with a provision of fixed time limit to transport the products from source to destination. It is the obligation of the transporter to get the endorsement from every check post in the route. Therefore the number of endorsements or re-confirming points depends on the number of districts and the distance to be crossed. 


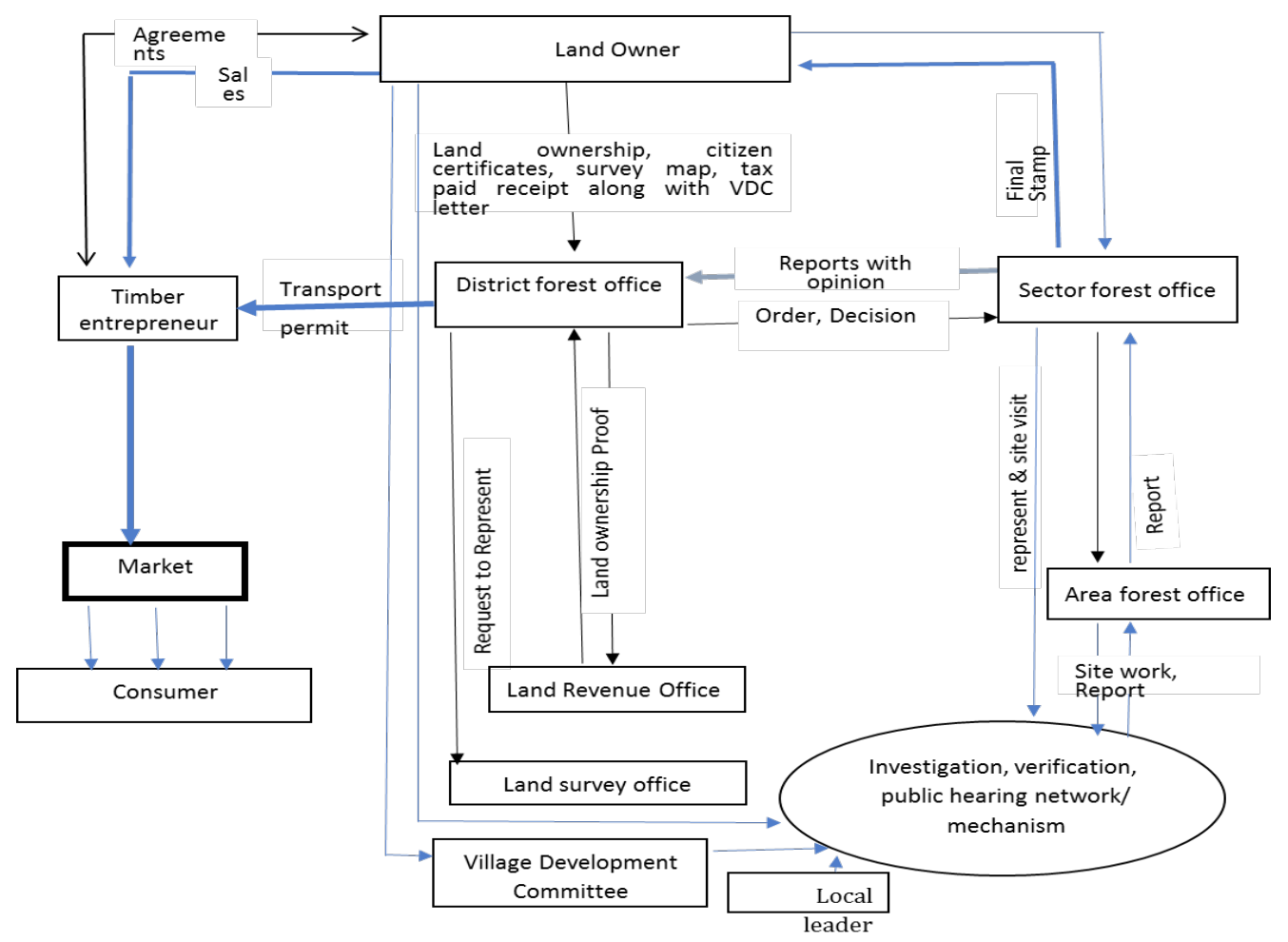

Figure 1: Selling and Distribution Processes for Timber from Private Forests (adapted from Amatya et al. 2015)

It is important to note at this point that there exists a conflict and contradiction in exercising these rights. Also, the lack of effective grievance mechanism and access of private owners to lodge complaints and conflict resolution is absent. Even the government cannot acquire private farmland without due process of law and without any compensation (GoN 1977). The individual has every right to use, exclude, and alienate the whole land, including the PF. However, there are certain pre-requisites and restrictions imposed by the government for the use of some commercial species of PF by an individual. This reflects the interest of government in the regulation of above-ground forest resources but not in the management of land. Further, the relationship and integral linkages between rights to manage, use, and alienate, and investments for the improved status of resources are overlooked and are undermined, which demotivates farmers from further investments in the development and management of PFs.

It has been found that almost all sawmills and forest-based entrepreneurs procure round logs from PFs through middlemen or contractors, both registered and unregistered (Figure 2). Middlemen or contractors, who are normally local agents without any institutional identity, play a vital role in procuring timber from PFs' owners and supplying it to sawmill owners. PF and tree owners generally do not carry out the administrative processes, harvesting, and marketing of 
forest products, as these processes are lengthy, cumbersome, and complex. In a study carried out in Kavrepalanchok and Sindhupalchok districts, Amatya et al. (2015) found that the harvesting and marketing of $\mathrm{PF}$ timber requires paperwork and demands time and effort from farmers. Less profitability as a result of this high transaction cost against small scale operation is incurred by the private owners. As the scale of work is small at the individual farmer level and as they lack the required knowledge and skills for administration, harvesting, and marketing, farmers prefer that the contractor undertake these responsibilities.

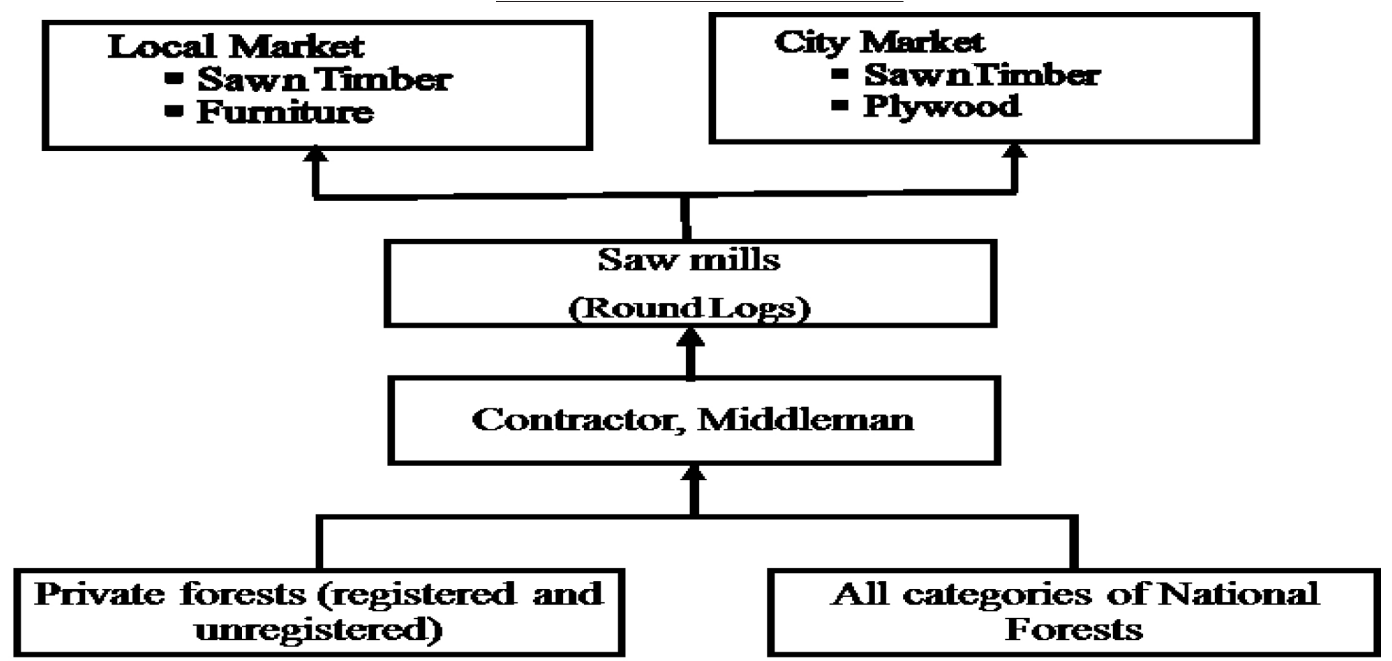

Figure 2: Timber Supply Mechanism (adapted from Amatya et al. 2015)

Amatya et al. (2015) revealed that all the paperwork, including tax payments, getting approval letters from DFOs, and other necessary documents required to procure logs from private forests are carried out by contractors. Pandit et al. (2014) have indicated that more than a week is needed to complete 14 steps of official formalities to harvest trees on private land. They have also documented the barriers in the value chain of PFs.

\section{KEY ISSUES AND CHALLENGES}

One of the main challenges is the time it takes to obtain the permit for harvesting and transport from three government agencies: Municipalities/Rural Municipalities, the Department of Land Revenue, and the Department of Cadastral Survey. In addition, cumbersome regulatory procedures, tax burdens additional to VAT (e.g., to local bodies or donations to various clubs en route to destination) and high transaction costs for harvesting and trade are considered as additional challenges. In order to register $\mathrm{PF}$, the DFO should carry out field investigations in coordination with Land Revenue and Land Survey Offices.

Farmers have limited access to improved tree seeds, new technologies, and market opportunities (DoF 2015). Because of the gap in technology of raising trees and knowledge of tree products, individuals are raising naturally occurring, poor quality tree species on their registered and unregistered PFs. The unavailability of 
quality planting materials and extension services have been another major constraint for private tree growers. Smallholders, who want to work on a small scale and have few trees, cannot afford high transaction costs and are deprived of anticipated returns.

Restrictions imposed by the government notifications have been major constraints in planting and raising high-value tree species on private lands. For example, the government has banned the harvest, transport, and export of Champ (Michelia champaka), Sal (Shorea robusta), Satisal (Dalberia latifolia), and Vijayasal (Pterocarpus marsupium) for commercial purposes (GoN 2001). However, the status of these species in the wild has never been assessed. The list of species recommended for planting in private land (GoN 2011) is also paradoxical. Despite the fact that individuals can't legally harvest Sal (Shorea robusta) tree even if they are planted and raised on private land, the Private Forest Development Directives of 2011 recommend it as on the species to be planted and raised on PFs. Furthermore, the collection, sale, transportation, and export of three NTFPs such as Panchaule (Dactylorbiza hatagiera), Okhar (Juglans regia) and Lichen species have also been banned. Similarly, five other species Jatamasi (Nardostachys grandiflora), Sughandakokila (Cinnamomum glaucescens), Sughandawal (Valeriana jatamansi), Talispatra (Abis spectabilis) and Lauth Sala (Taxus species) are prohibited for export in unprocessed form without permission from the DoF (GON 2001).

At present, DFOs don't have any official written obligations for registering PFs. Promotional programs limited to free registration, lack of good quality technical services, and free distribution of low- quality seedlings have not been able to attract farmers to register PFs. There is also a lack of financial incentive, including access to credit from financial institutions for PF owners to grow trees on their land. Such constraint disincentivises farmers and jeopardises the ability of farmers to exercise their forest property rights as spelled in the Forest Act 1993, Forest Policy 2015 and Forest Sector Strategy 2016. Instead of promoting the bundle of rights to be realised effectively and efficiently, regulatory procedures limit farmers' economies of scale, technical and marketing capacities, and access to microfinance, technical services, and quality seedlings. It can therefore be argued that despite the existence of favorable national-level policy and legal establishments, regulatory and programmatic provisions including the permit regimes are not favorable to PFs.

\section{CONCLUSION AND RECOMMENDATIONS}

The national policy discourse is generally positive in terms of promoting PF in Nepal. However, regulatory, programmatic, operational, and fiscal procedures are not in line with policy and legal provisions and therefore have not been able to convince farmers to register PFs. In addition, the lengthy and multi-stage harvesting and permit procedures prevent the full realization of property rights for PF owners and tree growers. Restrictions on harvesting, transportation, and selling of important commercial species has made farmers reluctant to invest in and grow such species on their private land even if they are of high value. This has thereby deprived farmers from realising their potential forestry incomes. 
Amidst these constraints, PF can be a major source for fulfilling timber market demands. Timber flows from PFs to the market over the last five years have constantly increased, and are considerably higher in comparison to those from community- and government- managed forests. This shows that people are more interested in planting trees and that they are aware of the benefits that they can get from private forest management. This trend can be attributed to market forces and expanding access roads in rural areas.

PFs can contribute to generating income and employment opportunities, check out-migration, enhance food security, and improve ecological balance and mitigate the effects of climate change to some extent. Various actions could be carried out to harness these potential benefits.

First, a study on the contribution of PFs in terms of National Gross Domestic Product would be helpful to convince the policy makers and promote appropriate regulations, programs, incentives, and technical support. These may include incentivising registration (e.g. providing financial resources and technical/material services, simplifying the registration process, and providing registration services easily), revising permit procedures towards less regulation, and revising bans on harvesting, transportation, and selling.

Second, DFO staff may need reorientation to adequately support $\mathrm{PF}$ and tree growers, and the procedures and incentives to promote PFs should be made transparent, clearer, and attractive through a variety of means (e.g., citizen charters, awareness campaigns, and mass media). Direct financial incentives can be provided to PF tree growers, such as by exempting or substantially reducing land taxes and relaxing VAT. Moreover, insurance for mature trees would further enhance the growing of trees on private lands.

Third, the provisioning of programs and services to enhance the capacity of forestmanaging farmers and communities in producing, harvesting, transporting, and selling forest products in larger quantities to harness greater benefits from the economy of scale is critical. Nepal's experience in community forestry would be of great asset to work towards this end. A PF supplement to the community forest operational guidelines may be prepared and put in place for implementation. Connecting community forests in cluster for organised and cooperative action, mobilizing their accumulated fund to provide access to micro credit for farmers growing trees in small scale can produce nationwide triggering effect to promote private forests.

\section{ACKNOWLEDGEMENTS}

We would like to thank Dr. Naya Sharma Paudel at Forest Action and Dr. Mani Ram Banjade at CIFOR for providing us with the opportunity to write this article.

\section{REFERENCES}

Acharya, D. P. and Baral N.R. 2016. Forestry Sector Governance and Private Sector. Ban Sanchar, 1: 3.

Amatya, S.M., Nuberg, I., Cedamon, E. and Pandit, B.H. 2015. Removing Barriers to the Commercialization of Agroforestry Trees in Nepal. In Proceedings of International IUFRO Symposium on Small-scale and Community Forestry and the Changing Nature of Forest Landscapes, 11-15 October 2015, Queensland, Sunshine Coast, Australia.

CBS. 2013. National Sample Census of Agriculture Nepal, 2011/12. Central Bureau of Statistics, Government of Nepal, Kathmandu, Nepal. 
CBS. 2015. Nepal in Figures 2015. Central Bureau of Statistics, Government of Nepal, Kathmandu, Nepal.

CFD. 2017. Official Records of the Community Forestry Division. Community Forestry Division, Department of Forests, Kathmandu, Nepal.

DoF. 2015. Present Status of Private Forest Management and Issues for Improvement. Report on Fifth DFO's National Workshop (pp. 111-115). Department of Forests, Government of Nepal, Kathmandu, Nepal.

FAO. 2014. Strengthening Forest Tenure Systems and Governance. Training Module for Facilitatorys. Rome: Food and Agriculture Organisation of the United Nations, Italy.

GoN. 1977. Land Acquisition Act, 2034 (1977), with Amendments 2010. Nepal Law Commission, Government of Nepal, Kathmandu, Nepal.
GoN. 2001. Notice of the Ministry of Forest and Soil Conservation. Nepal Gazette Part 3, December 31, 2001).

GoN. 2011. Private Forest Development Directives 2011. Ministry of Forests and Soil Conservation, Government of Nepal, Kathmandu, Nepal.

GoN. 2015. Forest Policy 2015. Ministry of Forests and Soil Conservation, Government of Nepal, Kathmandu, Nepal.

HMGN. 1993. Forest Act 1993 (Official Translation). Ministry of Forests and Soil Convervation, His Majesty's Government of Nepal, Kathmandu, Nepal.

Pandit, B. H., Neupane, R.P. and Bhattarai, S.S. 2014. Contribution of Agroforestry and Community Forestry to Food Security and Livelihoods of Rural People in Middle Hills of Nepal. A State of Knowledge Review. Nepal Agroforestry Foundation, Kathmandu, Nepal. 